\title{
The effect of hydrolysis duration on the phase composition, texture, aggregation and agglomeration of $\mathrm{ZrO}_{2}$ nanoparticles
}

\author{
Sh. O. Omarov \\ Ioffe Institute, Saint Petersburg, 194021, Russia \\ somarov@mail.ioffe.ru
}

PACS 81.20.-n, 61.46.+w, 81.10.-h, 64.70K

DOI 10.17586/2220-8054-2021-12-4-472-480

In this work, a number of $\mathrm{ZrO}_{2} \cdot n \mathrm{H}_{2} \mathrm{O}$ and $\mathrm{ZrO}_{2}$ samples were synthesized by direct precipitation and hydrolysis with different duration (36 and $61 \mathrm{~h}$ ) followed by neutralization and thermal treatment. The prepared samples were analyzed using DT-TGA, PXRD, $\mathrm{N}_{2}$ physisorption and LD methods. The dependence of the size of crystallites and secondary particles, phase composition, texture, and particle morphology on the amount of zirconium hydrolyzed to form $m-\mathrm{ZrO}_{2}$ is shown. The possibility of regulating the phase composition of $\mathrm{ZrO}_{2}$ has been established while maintaining the specific surface area $\left(110-120 \mathrm{~m}^{2} / \mathrm{g}\right)$, as well as creating a hierarchical system of micro-mesopores. The mechanism of the $\mathrm{ZrO}_{2} \cdot n \mathrm{H}_{2} \mathrm{O}$ formation during hydrolysis and precipitation is considered. The size of the critical nucleus is estimated $(1.5-2 \mathrm{~nm})$.

Keywords: zirconia, hydrolysis, phase composition, texture, aggregation, agglomeration, mechanism.

Received: 18 July 2018

\section{Introduction}

Zirconia has found application in the production of ceramic and catalysts, incl. those used in industrial applications [1-3]. It is considered that the tetragonal modification of $\mathrm{ZrO}_{2}\left(t-\mathrm{ZrO}_{2}\right)$ is preferable because it has a better porous structure, developed surface acidity, and defective structure. It was however shown $[4,5]$ that catalysts based on the monoclinic modification $\left(m-\mathrm{ZrO}_{2}\right)$ are more active but less stable by time om stream. Therefore, it is urgent to study in detail the possibility of obtaining $m-\mathrm{ZrO}_{2}$ with a more developed porous structure and to study the possibility of obtaining and controlling the $t-\mathrm{ZrO}_{2} / m-\mathrm{ZrO}_{2}$ ratio.

Precipitation from aqueous solutions of salts is the main method for the synthesis of $\mathrm{ZrO}_{2}$, during which nanosized $\mathrm{X}$-ray amorphous hydrous zirconia $\left(\mathrm{ZrO}_{2} \cdot n \mathrm{H}_{2} \mathrm{O}\right)$ is formed. This is an effective method for the preparation of $t-\mathrm{ZrO}_{2}$ nanocrystallites with a developed mesoporous structure, which is formed during thermal treatment at $350-$ $450^{\circ} \mathrm{C}$. There are other methods: hydrolysis of aqueous solutions of salts [6-9], hydrothermal treatment [10], solution combustion [11], thermal decomposition of salts [12], heterophase conversion [13], etc. Matsui et al. [6-9] showed that a sol consisting of $m-\mathrm{ZrO}_{2}$ nanoparticles (crystallites $2.2-4.9 \mathrm{~nm}$, agglomerates $100-200 \mathrm{~nm}$ ) is formed upon the long-term maintenance of a $\mathrm{ZrOCl}_{2}$ solution at $100{ }^{\circ} \mathrm{C}$ during complete hydrolysis of the salt. The hydrolysis reaction proceeded as follows:

$$
\mathrm{ZrOCl}_{2}+(n+1) \mathrm{H}_{2} \mathrm{O} \rightarrow \mathrm{ZrO}_{2} \cdot n \mathrm{H}_{2} \mathrm{O}+2 \mathrm{H}^{+}+2 \mathrm{Cl}^{-} .
$$

This method makes it possible to obtain phase-purified $m-\mathrm{ZrO}_{2}$. However, the results on the porous structure are absent in the listed works, and in [5] and other similar studies, only the value of the specific surface area is given. Salt concentration, temperature and duration of hydrolysis are the most important parameters of synthesis [9]. Extraneous cations $\left(\mathrm{Al}^{3+}, \mathrm{Ca}^{2+}\right)$ have no effect [7], while the presence of $\mathrm{HCl}, \mathrm{NaCl}, \mathrm{NH}_{4} \mathrm{OH}$ allows regulation of the rate and completeness of hydrolysis, crystallite size and agglomerates of $m-\mathrm{ZrO}_{2}$ due to a decrease in the effect of the electric double layer and an increase in heterocoagulation [6-8]. However, the intermediate states remained unexplored, when only a part of the primary forms of zirconium passed into the sol during complete hydrolysis. The residual solution can be neutralized with a base solution, thus allowing the phase composition of $\mathrm{ZrO}_{2}$ to be adjusted.

In this work, the effect of the hydrolysis duration of a $\mathrm{ZrOCl}_{2}$ solution, additionally neutralized with an $\mathrm{NH}_{4} \mathrm{OH}$ solution, on the structural and morphological properties of $\mathrm{ZrO}_{2} \cdot n \mathrm{H}_{2} \mathrm{O}$ and $\mathrm{ZrO}_{2}$ is analyzed. The phase composition, crystallite size, porous structure and agglomeration during neutralization are studied by a complex of physicochemical methods to establish the formation mechanism, and to assess the possibility of obtaining $\mathrm{ZrO}_{2}$ with the required porous structure. The obtained results and the formation mechanism are discussed from the point of view of non-classical concepts of nucleation and crystal growth. 


\section{Experimental}

\subsection{Synthesis technique}

A $0.2 \mathrm{M} \mathrm{ZrOCl}_{2}$ solution was used as the initial solution. For this, $25.78 \mathrm{~g}$ of $\mathrm{ZrOCl}_{2} \cdot 8 \mathrm{H}_{2} \mathrm{O}$ was dissolved in $200 \mathrm{ml}$ of doubly distilled water and the volume of the solution was brought to $400 \mathrm{ml}\left(\rho=1.027 \mathrm{~g} / \mathrm{cm}^{3}\right)$. The hydrolysis was carried out in a three-necked borosilicate glass flask in a batch mode $\left(8 \mathrm{~h}\right.$ at $(100 \pm 1){ }^{\circ} \mathrm{C}-16 \mathrm{~h}$ at room temperature). The timing began when the solution temperature reached $95{ }^{\circ} \mathrm{C}$. Sol samples with a volume of $95 \mathrm{ml}$ were taken after $36 \pm 2$ and $61 \pm 3 \mathrm{~h}$. The final hydrolysis time of the remaining sol was $126 \pm 4 \mathrm{~h}$. The resulting sols were neutralized by adding a $13 \mathrm{M}$ ammonia solution $\left(\rho=0.909 \mathrm{~g} / \mathrm{cm}^{3}\right.$ at $\left.20^{\circ} \mathrm{C}\right)$ to $\mathrm{pH}=9.1$. The preparation of $\mathrm{ZrO}_{2} \cdot n \mathrm{H}_{2} \mathrm{O}$ by direct precipitation from a $0.6 \mathrm{M} \mathrm{ZrOCl}_{2}$ solution with a $13 \mathrm{M}$ ammonia solution is described in [1].

Then the mother liquor was vacuum filtered using a Buchner funnel. The resulting mass was washed via decantation until there was no $\mathrm{Cl}^{-}\left(\sim 0.2 \mathrm{~L} \mathrm{H}_{2} \mathrm{O} / \mathrm{g} \mathrm{ZrO}_{2}\right.$, controlled with $\left.0.1 \mathrm{~N} \mathrm{AgNO}_{3}\right)$. After washing, the mother liquor was squeezed out, and the resulting mass was dried for $4 \mathrm{~h}$ at $60{ }^{\circ} \mathrm{C}$ and $1 \mathrm{~h}$ at $90{ }^{\circ} \mathrm{C}$. To study the pore structure and phase composition of $\mathrm{ZrO}_{2}$, the $\mathrm{ZrO}_{2} \cdot n \mathrm{H}_{2} \mathrm{O}$ samples were subjected to thermal treatment in a muffle furnace in the stepwise mode of $170{ }^{\circ} \mathrm{C}, 0.5 \mathrm{~h} ; 250{ }^{\circ} \mathrm{C}, 0.5 \mathrm{~h} ; 300-500{ }^{\circ} \mathrm{C}, 0.5 \mathrm{~h}$. The temperature growth rate was $4{ }^{\circ} \mathrm{C} / \mathrm{min}$. The samples are denoted as $\mathrm{ZrO}_{2}-\mathrm{P} / \mathrm{H}(\mathrm{x})-y$, where $P$ - precipitation method, $H(x)$ - hydrolysis method and its duration, $\mathrm{h}, y$ - treatment temperature, ${ }^{\circ} \mathrm{C}$.

\subsection{Characterization methods}

Synchronous thermal analysis of $\mathrm{ZrO}_{2} \cdot n \mathrm{H}_{2} \mathrm{O}$ samples was conducted on a Shimadzu DTG-60A thermal analyzer. The weighed portion of a sample was $16-20 \mathrm{mg}$; the material of the crucibles and the reference was corundum; the heating rate was $10{ }^{\circ} \mathrm{C} / \mathrm{min}$. The heat of crystallization data was used to determine the proportion of $\mathrm{ZrO}_{2}$ that passed into the solid phase as a result of hydrolysis:

$$
a_{H}=\left(1-\frac{\Delta Q\left(\mathrm{ZrO}_{2}-H(x)\right)}{\Delta Q\left(\mathrm{ZrO}_{2}-P\right)} \times 100 \%\right) .
$$

Characteristics of the pore structure of $\mathrm{ZrO}_{2} \cdot n \mathrm{H}_{2} \mathrm{O}$ and $\mathrm{ZrO}_{2}$ were identified via the low-temperature sorption of $\mathrm{N}_{2}$ on a Quantachrome Autosorb 6iSA instrument at $77 \mathrm{~K}$. Before analysis, the samples were degassed in vacuum for $1 \mathrm{~h}$ at $100{ }^{\circ} \mathrm{C}$ (for $\mathrm{ZrO}_{2} \cdot n \mathrm{H}_{2} \mathrm{O}$ ) or $250{ }^{\circ} \mathrm{C}$ (for $\mathrm{ZrO}_{2}$ ). Specific surface area $\left(\mathrm{S}_{B E T}, \mathrm{~m}^{2} / \mathrm{g}\right.$ ) was calculated using the Brunauer-Emmett-Teller (BET) technique; total pore volume $\left(V_{\Sigma}, \mathrm{cm}^{3} / \mathrm{g}\right)$ was determined from the limiting value of absorbed $\mathrm{N}_{2}$ at $p / p_{0}=0.97$; pore size distribution was calculated according to the density functional theory [14].

The phase composition and crystalline size of the $\mathrm{ZrO}_{2}$ samples were studied by powder X-ray diffraction on a Shimadzu XRD-6100 diffractometer (Cu anode, Ni filter) using D:S:R $=0.5^{\circ}: 0.5^{\circ}: 0.15 \mathrm{~mm}$ slits in the step of $0.02^{\circ}$ with an acquisition time of $3 \mathrm{~s}$ per point. The volume fraction of the tetragonal phase $\left(t-\mathrm{ZrO}_{2}, \mathrm{~V}_{t}\right.$, vol.\%) was calculated as described in [15]. The Scherrer equation $\left(K=0.94 ; \lambda\left(\mathrm{CuK}_{\alpha 1}\right)=0.15406 \mathrm{~nm}\right)$ was used to calculate the crystalline size of $t-\mathrm{ZrO}_{2}\left(d_{t}, \mathrm{~nm}\right)$ and $m-\mathrm{ZrO}_{2}\left(d_{m}, \mathrm{~nm}\right)$.

The size distribution of particles in the as-synthesized $\mathrm{ZrO}_{2} \cdot n \mathrm{H}_{2} \mathrm{O}$ sols and colloidal suspensions were investigated by laser diffraction (LD) on a "Shimadzu SALD-2300" particle size analyzer. For this, colloidal suspensions of the samples were prepared by mixing $80 \mathrm{mg}$ of the product with $250 \mathrm{~mL}$ of distilled water and sonicating the mixture for $3 \mathrm{~min}$ by a $700 \mathrm{~W}$ ultrasonic disperser. The Refractive index was 1.85 .

\section{Results and discussion}

\subsection{Simultaneous TG-DTA}

Fig. 1 and Table 1 shows results from simultaneous thermal analysis of $\mathrm{ZrO}_{2} \cdot n \mathrm{H}_{2} \mathrm{O}$ samples. Two regions can be distinguished from the differential thermal curves.

In the first region $\left(20-300{ }^{\circ} \mathrm{C}\right), \mathrm{ZrO}_{2} \cdot n \mathrm{H}_{2} \mathrm{O}$ underwent two steps of dehydration: the desorption of unbound water $\left(\Delta m_{1}\right)$ and the removal of structural water during the thermal decomposition of oxyhydroxide $\left(\Delta m_{2}\right)$ [16]. An increase in the hydrolysis duration leads to a non-monotonic increase in the amount of structural water and the total amount of water $n$ (Table 1). Wherein the content of unbound water changes insignificantly. The $\mathrm{ZrO}_{2}-\mathrm{H}(36)$ sample has the highest hydration, and the $\mathrm{ZrO}_{2}-\mathrm{H}(126)$ sample has the lowest.

Crystallization of X-ray amorphous $\mathrm{ZrO}_{2}\left(a-\mathrm{ZrO}_{2}\right)$ obtained after dehydration of $\mathrm{ZrO}_{2} \cdot n \mathrm{H}_{2} \mathrm{O}$ occurs in the second region $\left(370-470{ }^{\circ} \mathrm{C}\right)$. Here, weight loss $\left(\Delta m_{3}\right)$ is also observed, which does not depend on the hydrolysis duration. The $\mathrm{ZrO}_{2}-\mathrm{P}$ sample obtained by precipitation is characterized by the maximum heat of crystallization of $a-\mathrm{ZrO}{ }_{2}(\Delta Q)$. The crystallization peak of $a-\mathrm{ZrO}_{2}$ for the $\mathrm{ZrO}_{2}-\mathrm{H}(126)$ sample is insignificant. The $\Delta Q$ value and the crystallization onset temperature $\left(\mathrm{T}_{\text {init }}\right)$ decrease with increasing the hydrolysis duration (Table 1). This regularity indicates an increase in the content of the hydrolysis product and, accordingly, a decrease in the content of $a-\mathrm{ZrO}_{2} \cdot n \mathrm{H}_{2} \mathrm{O}$, formed 

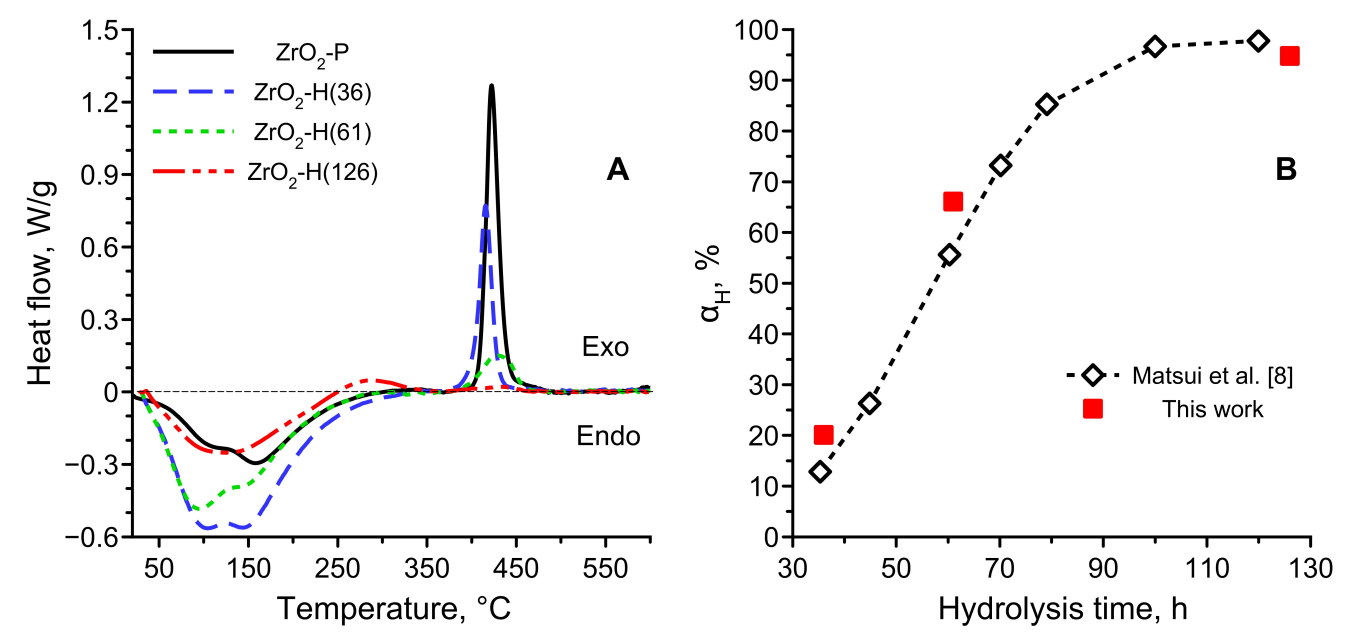

FIG. 1. DT-curves of samples (A) and results of determining the fraction of hydrolyzed zirconia

TABLE 1. Results from the simultaneous TG-DTA of $\mathrm{ZrO}_{2} \cdot n \mathrm{H}_{2} \mathrm{O}$

\begin{tabular}{|c|c|c|c|c|c|c|}
\hline \multirow{3}{*}{ Sample } & \multirow{3}{*}{$n \mathrm{H}_{2} \mathrm{O}^{*}$} & \multicolumn{3}{|c|}{ Weight loss, wt $\%$} & \multirow{2}{*}{\multicolumn{2}{|c|}{$a-\mathrm{ZrO}_{2}$ crystallization }} \\
\hline & & $\Delta m_{1}$ & $\Delta m_{2}$ & $\Delta m_{3}$ & & \\
\hline & & $20-125^{\circ} \mathrm{C}$ & $125-300^{\circ} \mathrm{C}$ & $300-800^{\circ} \mathrm{C}$ & $\Delta Q, \mathrm{~J} / \mathrm{g} \mathrm{ZrO}{ }_{2}$ & $\mathrm{~T}_{\text {init }},{ }^{\circ} \mathrm{C}$ \\
\hline $\mathrm{ZrO}_{2}-\mathrm{P}$ & 1.16 & 2.4 & 9.7 & 2.4 & 130 & 411 \\
\hline $\mathrm{ZrO}_{2}-\mathrm{H}(36)$ & 1.54 & 3.6 & 11.6 & 3.2 & 102 & 402 \\
\hline $\mathrm{ZrO}_{2}-\mathrm{H}(61)$ & 1.20 & 4.0 & 7.4 & 3.4 & 43 & 397 \\
\hline $\mathrm{ZrO}_{2}-\mathrm{H}(126)$ & 0.80 & 2.1 & 5.2 & 3.2 & $\sim 7$ & - \\
\hline
\end{tabular}

during the neutralization of partially hydrolyzed solutions. The change in the heat of crystallization made it possible to estimate the amount of $\mathrm{ZrO}_{2} \cdot n \mathrm{H}_{2} \mathrm{O}\left(\alpha_{H}\right)$ formed during complete hydrolysis (Fig. 1B). Comparison with the results [6-9], which determined $\alpha_{H}$ by chelation titration, shows a similar dependence and close absolute values of $\alpha_{H}$.

\subsection{Powder X-Ray diffraction}

The results of X-ray diffraction are shown in Fig. 2 and Table 2. The $\mathrm{ZrO}_{2}-\mathrm{P}$ sample obtained by precipitation is characterized by an X-ray amorphous state, which corresponds to the halo (Fig. 2A). The content of the poorly crystallized $m-\mathrm{ZrO}_{2}$ phase in the resulting precipitates increased with longer hydrolysis durations. The formation of a mixture of $m-\mathrm{ZrO}_{2} \cdot n \mathrm{H}_{2} \mathrm{O}$ and $a-\mathrm{ZrO}_{2} \cdot n \mathrm{H}_{2} \mathrm{O}$ (hydrolysis duration of 36 and $61 \mathrm{~h}$ ) was associated with the partial formation of $m-\mathrm{ZrO}_{2}$ during hydrolysis of $\mathrm{ZrOCl}_{2}$, as well as the precipitation from residual $\mathrm{ZrOCl}_{2}$ upon neutralization with an ammonia solution, respectively. This was consistent with the results of TG-DTA: the content of the crystalline $m-\mathrm{ZrO}_{2}$ increases. with lengthening the hydrolysis duration. The crystallite size (coherent scattering region) of $m-\mathrm{ZrO}_{2}$ increased with the hydrolysis duration reaching $3.4 \mathrm{~nm}$ (Table 2) upon hydrolysis for $126 \mathrm{~h}$, which was consistent with prior results [8].

Significant changes in the phase composition and crystallite size of the $\mathrm{ZrO}_{2}-\mathrm{P}$ sample occurred after thermal treatment at $450{ }^{\circ} \mathrm{C}$, which corresponds to the completion of the $a-\mathrm{ZrO}_{2}$ crystallization: a mixture of $t$ - and $m$ - $\mathrm{ZrO}$ is formed with a predominance of $t-\mathrm{ZrO}_{2}$ (Fig. 2B). The fraction of $m-\mathrm{ZrO}_{2}$ increased, and the size of the crystallites of $m-\mathrm{ZrO}_{2}$ and $t-\mathrm{ZrO}_{2}$ decreased with longer hydrolysis times in the samples thermally-treated at $450{ }^{\circ} \mathrm{C}$ (Table 2 ).

The formation of metastable $t-\mathrm{ZrO}_{2}$ during crystallization and its further polymorphic transformation into $m$ $\mathrm{ZrO}_{2}$ is explained by the structural similarity of $a-\mathrm{ZrO}_{2}$ and $t-\mathrm{ZrO}_{2}$ [17], and the achievement of the critical crystallite size of about $30 \mathrm{~nm}$, previously obtained [18] based on thermodynamic considerations about the influence of surface energy, respectively. However, the critical size of the $t-\mathrm{ZrO}_{2}$ crystallite depends on the conditions of synthesis, and subsequent processing of $\mathrm{ZrO}_{2}$ and can be much less than $30 \mathrm{~nm}$ [19]. The crystallite size of $t-\mathrm{ZrO}_{2}$ is different for 

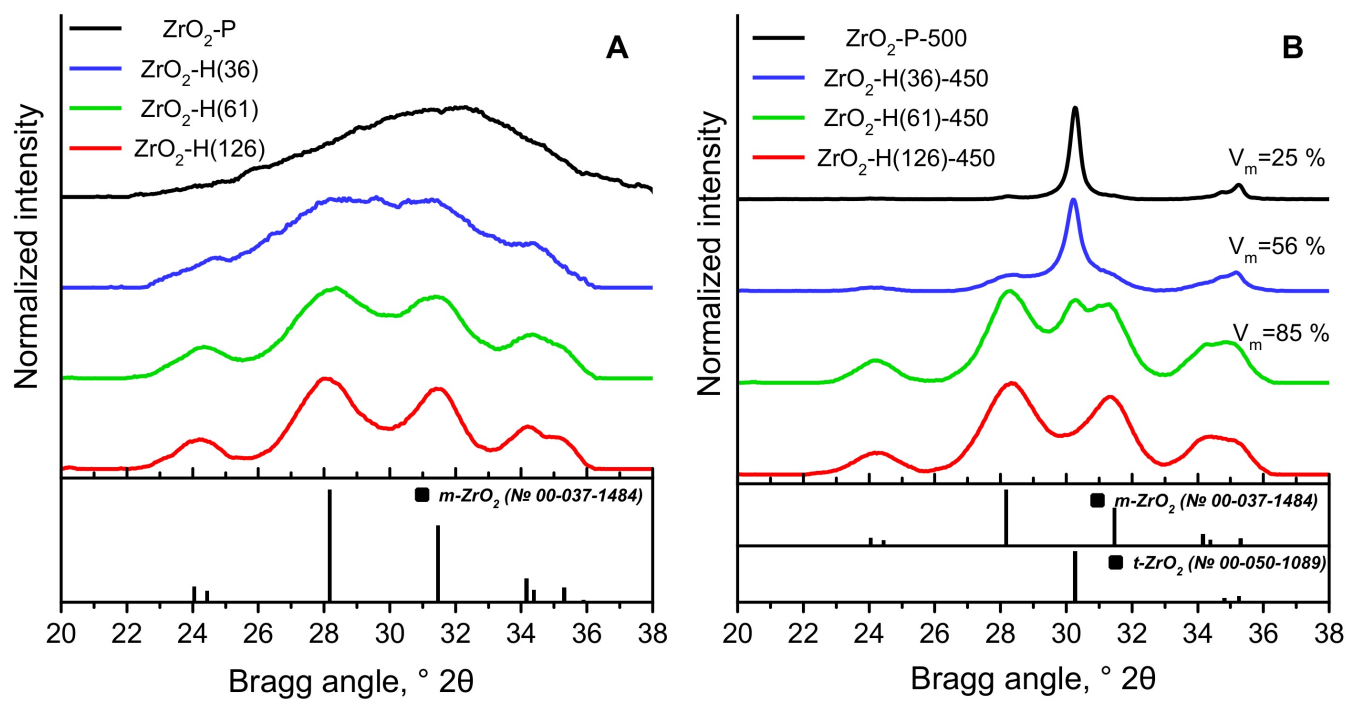

FIG. 2. XRD results of the as-prepared (A) and thermal treatment samples (B)

TABLE 2. $m-\mathrm{ZrO}_{2}$ crystalline size ( $d_{t}$ given in parentheses)

\begin{tabular}{|c|c|c|c|c|c|c|}
\hline \multirow{2}{*}{$\begin{array}{c}\text { Hydrolysis } \\
\text { duration, } h\end{array}$} & \multicolumn{7}{|c|}{ Thermal treatment, ${ }^{\circ} \mathrm{C}$} \\
\cline { 2 - 7 } & 100 & 300 & 350 & 450 & 500 & 600 \\
\hline 0 (precipitation) & $<2$ & - & - & - & $13.9(24.1)$ & - \\
\hline 36 & 2.1 & - & 3.6 & $5.3(14.4)$ & - & - \\
\hline 61 & 3.1 & - & 3.9 & $5.5(8.3)$ & - & - \\
\hline 126 & 3.4 & 3.7 & 3.8 & 4.2 & 4.4 & 5.8 \\
\hline
\end{tabular}

samples that differ in the duration of hydrolysis and heat-treated at $450-500{ }^{\circ} \mathrm{C}$ (Table 2). The imposition of the kinetic factor proposed in [20], namely, only a part of the crystallites with a size above a critical value pass into a new phase, explain the observed decrease in $d_{t}$. The formation of $m-\mathrm{ZrO}_{2}$ crystallites smaller than $t-\mathrm{ZrO}_{2}$ can be explained by twinning [21].

An increase in the treatment temperature of $\mathrm{ZrO}_{2}-\mathrm{H}(126)$ leads to a gradual increase in the size of $m$ - $\mathrm{ZrO}_{2}$ crystallites (Table 2). A noticeable change in $d_{m}$ begins to occur at $\mathrm{T} \geq 300^{\circ} \mathrm{C}$, and a sharp increase occurs at $600{ }^{\circ} \mathrm{C}$. After crystallization of $a-\mathrm{ZrO}_{2}$, a stronger increase in the size of $m-\mathrm{ZrO}_{2}$ crystallites occurs than with an increase in temperature from 100 to $350{ }^{\circ} \mathrm{C}$ in the case of samples with an intermediate duration of hydrolysis. This is due to the contribution of the $t-\mathrm{ZrO}_{2} \rightarrow m-\mathrm{ZrO}_{2}$ transition, which results in the formation of larger $m-\mathrm{ZrO}_{2}$ crystallites.

\section{Porous structure}

The results of studying the texture of samples by the $\mathrm{N}_{2}$ physisorption method are shown in Fig. 3 and Fig. 4. The isotherm for the $\mathrm{ZrO}_{2}-\mathrm{P}-500$ sample obtained by precipitation belongs to type IVa with an $\mathrm{H} 4$ hysteresis loop, which corresponds to a mesoporous structure according to IUPAC [14]. The contribution of the type I isotherm on the isotherms of the corresponding thermally treated samples increases with lengthening the hydrolysis duration. In this case, the hysteresis loops are retained and the contribution of the type IVa isotherm is present. The listed characteristics of the isotherms indicate the presence of micro- and mesopores in the texture of the samples. For the $\mathrm{ZrO}_{2}-\mathrm{H}(61)-500$ sample, a change in the type of hysteresis to $\mathrm{H} 3$ is observed, and for which it can be assumed that the pores are formed by aggregates of plot-like particles. In samples $\mathrm{ZrO}_{2}-\mathrm{H}(126)-300$ and $\mathrm{ZrO}_{2}-\mathrm{H}(126)-500$, the hysteresis loops are small; therefore, the texture is mainly represented by micropores.

The conclusions based on the isotherms are confirmed by the results of calculating the pore size distribution curves. Samples $\mathrm{ZrO}_{2}-\mathrm{P}-500$ and $\mathrm{ZrO}_{2}-\mathrm{H}(36)-500$, in the preparation of which the precipitation product predominated, are represented by small mesopores $2-10 \mathrm{~nm}$. The proportion of micropores simultaneously increases with the 

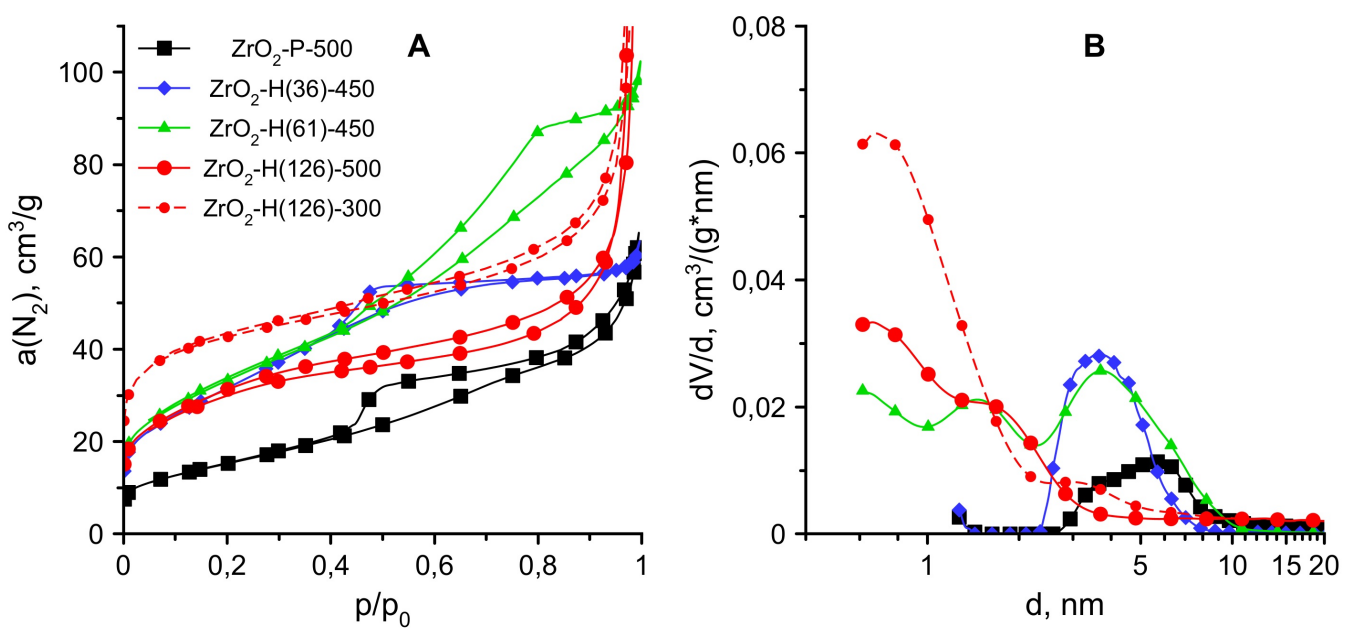

FIG. 3. $\mathrm{N}_{2}$ physisorption isotherms (A) and pore size distribution (B) for $\mathrm{ZrO}_{2}$ samples

contribution of hydrolysis to the formation of $\mathrm{ZrO}_{2}$ (samples $\mathrm{ZrO}_{2}-\mathrm{H}(126)-300$ and $\left.\mathrm{ZrO}_{2}-\mathrm{H}(126)-500\right)$. The absorption of a large amount of nitrogen at $p / p_{0}>0.97$ is a feature of the sorption isotherms of the $\mathrm{ZrO}_{2}-\mathrm{H}(126)-300$ and $\mathrm{ZrO}_{2}-\mathrm{H}(126)-500$ samples. The corresponding pore size distribution curves show nonzero $\mathrm{dV} / \mathrm{d}$ values at diameters greater than $5 \mathrm{~nm}$ (Fig. 3B) and the presence of a local maximum at $70 \mathrm{~nm}$ (not shown here). This may be due to the presence of secondary porosity formed by the gap between agglomerates (secondary particles).

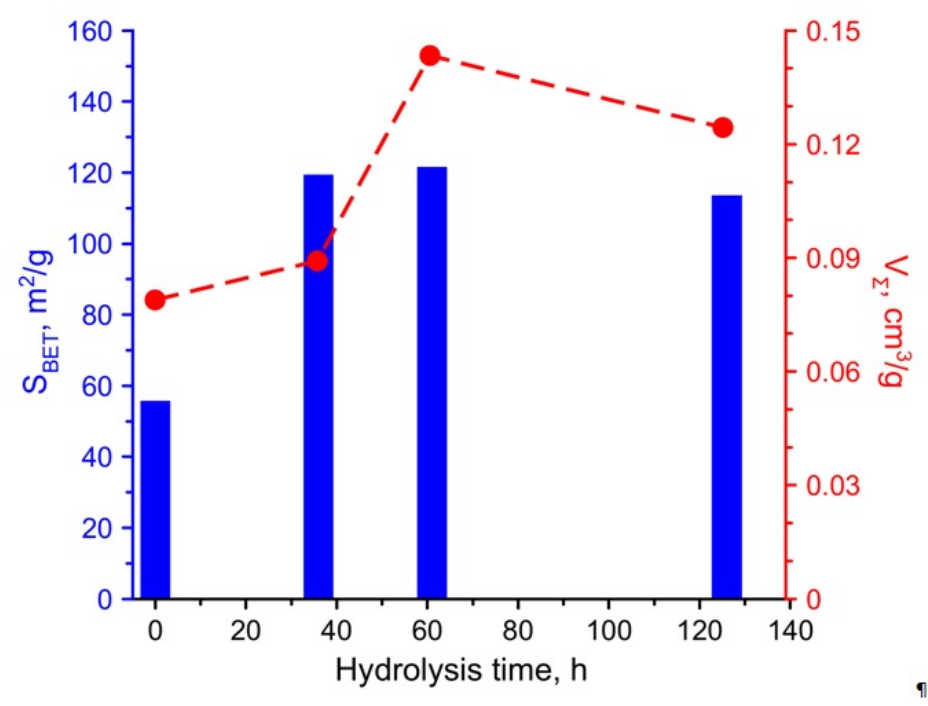

FIG. 4. Dependence of specific surface area and total pore volume vs hydrolysis duration for thermal treatment at $450-500{ }^{\circ} \mathrm{C}$ samples

The specific surface area of $\mathrm{ZrO}_{2}$ increases with lengthening the hydrolysis duration (Fig. 4). A similar dependence is observed for $V_{\Sigma}$ at $p / p_{0}=0.97$. The specific surface area of the $\mathrm{ZrO}_{2}-\mathrm{H}(126)$ sample obtained by complete hydrolysis decreases from 156 to $113 \mathrm{~m}^{2} / \mathrm{g}$, and the total pore volume from 0.149 to $0.124 \mathrm{~cm}^{3} / \mathrm{g}$ with an increase in the treatment temperature from 300 to $500{ }^{\circ} \mathrm{C}$. High $S_{B E T}$ and $V_{\Sigma}$ correspond to loose packing of crystallites. The appearance in the phase composition of an amount of $m-\mathrm{ZrO}_{2}$ comparable to the amount of $t-\mathrm{ZrO}_{2}\left(\right.$ sample $\mathrm{ZrO}_{2}-$ $\mathrm{H}(36)-450)$, and reduced size of $t-\mathrm{ZrO}_{2}$ crystallites contribute to a noticeable increase in $S_{B E T}$ with lengthening the hydrolysis duration from 0 to $36 \mathrm{~h}$ (samples $\mathrm{ZrO}_{2}-\mathrm{P}-500$ and $\mathrm{ZrO}_{2}-\mathrm{H}(36)-450$, respectively). Poorly crystallized $m-\mathrm{ZrO}_{2}$, which has a high $S_{B E T}$ (sample $\left.\mathrm{ZrO}_{2}-(\mathrm{H} 126)-450\right)$, begins to make a greater contribution to $S_{B E T}$ with a further increase in the duration of hydrolysis to $61 \mathrm{~h}$. The obtained $\mathrm{S}_{B E T}$ values of $\mathrm{ZrO}_{2}-\mathrm{H}(36)-450$ and $\mathrm{ZrO} \mathrm{r}_{2}-$ $\mathrm{H}(61)-450$ exceed the sum of $\mathrm{S}_{B E T}$ of individual $t-\mathrm{ZrO}_{2}$ and $m-\mathrm{ZrO}_{2}$ samples $\mathrm{ZrO}_{2}-\mathrm{P}-500$ and $\mathrm{ZrO}_{2}-(\mathrm{H} 126)-450$, respectively, taking into account their share in the phase composition. 
There is an inverse proportionality between the crystallite size of the phases and $\mathrm{S}_{B E T}$ according to the ratio:

$$
d_{A d s}=\frac{A}{S_{B E T} \times \rho},
$$

where $\rho$ - density, $A$ - coefficient depending on the shape of the crystallites. The calculation of $d_{A d s}$ according to formula (3) and data on $S_{B E T}$ taking into account the density of the predominant phase $\left(6.134 \mathrm{~g} / \mathrm{cm}^{3}\right.$ for $t-\mathrm{ZrO}_{2}$ and $5.817 \mathrm{~g} / \mathrm{cm}^{3}$ for $\left.m-\mathrm{ZrO}_{2}\right)$ for different morphologies of particles $(A=6$ for spherical, $A=4$ for rod-shaped and $A=2$ for plate-like particles) showed that $d_{A d s}$ values closest to $d_{X R D}$ for samples with a predominance of $m-\mathrm{ZrO}_{2}$ are achieved under the assumption of a plate-like or rod-shaped particle and in the case of the predominance of $t-\mathrm{ZrO}_{2}$ assuming a spherical shape (Table 3). The order of the $d_{X R D}$ and $d_{A d s}$ values is the same. Consequently, the specific surface area calculated from the $\mathrm{N}_{2}$ sorption data is determined precisely by crystallites, and the formation of larger agglomerates and aggregates does not affect its value. It should be noted that the initial non-heat treated $\mathrm{ZrO}_{2}-\mathrm{P}$ sample with $S_{B E T}=231 \mathrm{~m}^{2} / \mathrm{g}$ has an equivalent particle size of $1.8 \mathrm{~nm}$ in the approximation of lamellar morphology ( $\rho=4.86 \mathrm{~g} / \mathrm{cm}^{3}[22]$ ), which corresponds to the PXRD result on its X-ray amorphous state (Table 2).

TABLE 3. Particle size $\mathrm{d}_{S S A}$ values calculated using equation (3)

\begin{tabular}{|c|c|c|c|}
\hline Sample & $\begin{array}{c}d_{\text {Ads }}(A=6), \\
\mathrm{nm}\end{array}$ & $\begin{array}{c}d_{\text {Ads }}(A=4), \\
\mathrm{nm}\end{array}$ & $\begin{array}{c}d_{\text {Ads }}(A=2), \\
\mathrm{nm}\end{array}$ \\
\hline $\mathrm{ZrO}_{2}-\mathrm{P}$ & 5.3 & 3.6 & 1.8 \\
\hline $\mathrm{ZrO}_{2}-\mathrm{P}-500$ & 17.5 & 11.6 & 5.8 \\
\hline $\mathrm{ZrO}_{2}-\mathrm{H} 36-450$ & 8.2 & 5.4 & 2.7 \\
\hline $\mathrm{ZrO}_{2}-\mathrm{H} 61-450$ & 8.5 & 5.6 & 2.8 \\
\hline $\mathrm{ZrO}_{2}-\mathrm{H} 126-300$ & 6.6 & 4.4 & 2.2 \\
\hline $\mathrm{ZrO}_{2}-\mathrm{H} 126-500$ & 9.1 & 6.1 & 3.0 \\
\hline
\end{tabular}

\section{Laser diffraction}

The resulting dispersed systems visually differed in sedimentation and coagulation stability. $\mathrm{The}_{\mathrm{ZrO}} \cdot n \mathrm{H}_{2} \mathrm{O}$ sol obtained by hydrolysis of a $\mathrm{ZrOCl}_{2}$ solution for $126 \mathrm{~h}\left(\mathrm{ZrO}_{2}-\mathrm{H}(126)\right.$ sol, Fig. 5) was characterized by a small size of secondary particles (agglomerates $210 \mathrm{~nm}$ ) and a narrow size distribution. The sol of this sample was characterized by sedimentation and coagulation stability since noticeable signs of sedimentation were detected after several days, and ultrasonic treatment did not affect the given distribution. The results of laser diffraction for the $\mathrm{ZrO}_{2}-\mathrm{H}(126) \mathrm{sol}$ agreed with the results [6], where the TEM method showed the formation of agglomerates with a size of $170 \mathrm{~nm}$ upon hydrolysis of a $0.2 \mathrm{M} \mathrm{ZrOCl}_{2}$ solution. For the sol obtained after $36 \mathrm{~h}$ of hydrolysis, the distributions could not be measured due to the low concentration of particles, while for the sol obtained after $61 \mathrm{~h}$ of hydrolysis, the distributions differ little from the distribution for $\mathrm{ZrO}_{2}-\mathrm{H}(126)$, and the mean diameter was $0.20 \mu \mathrm{m}$. Active coagulation of the primary parts with the formation of nanoscale agglomerates occurred during the first $60 \mathrm{~h}$ of hydrolysis, at which $60 \%$ conversion of $\mathrm{ZrOCl}_{2}$ to $m-\mathrm{ZrO}_{2} \cdot n \mathrm{H}_{2} \mathrm{O}$ was achieved. The obtained results partially agree with the results [23, 24], where it was shown by the DLS method that active growth of agglomerates was observed in the first $30-40 \mathrm{~h}$ of hydrolysis, and the time interval decreased to $\sim 20 \mathrm{~h}$ with an increase in the initial concentration of the $\mathrm{ZrOCl}_{2}$ solution.

Neutralization of the resulting sol with an ammonia solution is a common technique [5, 25], which makes it possible to simplify the subsequent washing of the precipitate from $\mathrm{Cl}^{-}$and separation from the mother liquor. The addition of ammonia promotes additional coagulation of the sol, the formation of aggregates larger by an order $\left(\mathrm{ZrO}_{2}-\right.$ $\mathrm{H}(126)$ suspension, Fig. 5), and the appearance of a bimodal distribution. The lack of coagulation stability of the $\mathrm{ZrO}_{2}-\mathrm{H}(126)$ suspension led to a gradual coarsening of the aggregates, and the size distribution became close to that of the $\mathrm{ZrO}_{2}-\mathrm{P}$ suspension. The aggregates of particles of the sample obtained by direct precipitation $\left(\mathrm{ZrO}_{2}-\mathrm{P}\right.$ suspension, Fig. 5) had an even larger size and retained a bimodal distribution.

\section{Formation mechanism}

According to [26,27], during the dissolution of $\mathrm{ZrOCl}_{2}$ because of hydrolysis and primary polymerization, zirconium is in solution mainly in two forms, between which there is a mobile equilibrium depending on $\mathrm{pH}$ : $\left[\mathrm{Zr}_{4}(\mathrm{OH})_{8}\left(\mathrm{H}_{2} \mathrm{O}\right)_{16}\right]^{8+}$ and $\left[\mathrm{Zr}_{8}(\mathrm{OH})_{20}\left(\mathrm{H}_{2} \mathrm{O}\right)_{24}\right]^{12+}$. The $0.2 \mathrm{M} \mathrm{ZrOCl}_{2}$ solution used in this work had a $\mathrm{pH}$ equal to 


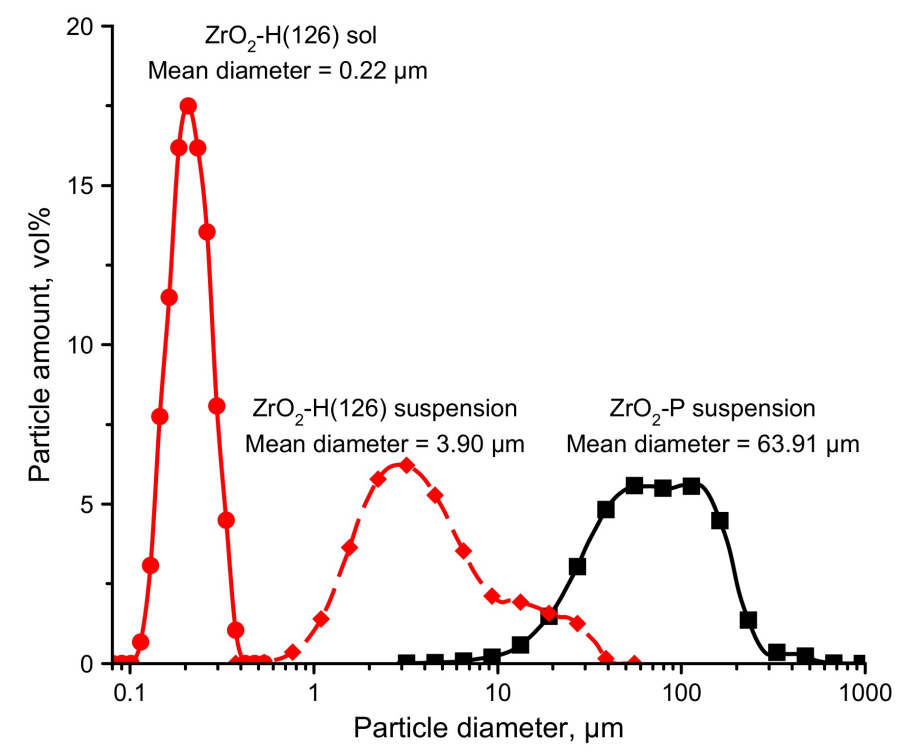

FIG. 5. Agglomerate and aggregate size distribution of the sol and suspensions

0.9 and 0.5 at 20 and $90{ }^{\circ} \mathrm{C}$, respectively, which indicates the predominant presence of zirconium in $\left[\mathrm{Zr}_{4}(\mathrm{OH})_{8}\left(\mathrm{H}_{2} \mathrm{O}\right)_{16}\right]^{8+}$ form. The $\mathrm{pH}$ of the resulting suspensions after 36,61 , and $126 \mathrm{~h}$ of hydrolysis was $0.4-$ 0.5 at $20{ }^{\circ} \mathrm{C}$. Consequently, the form $\left[\mathrm{Zr}_{4}(\mathrm{OH})_{8}\left(\mathrm{H}_{2} \mathrm{O}\right)_{16}\right]^{8+}$ predominated at any time of hydrolysis.

The above data shows the following. $\mathrm{X}$-ray amorphous $\mathrm{ZrO}_{2} \cdot n \mathrm{H}_{2} \mathrm{O}$ is formed during direct precipitation from a $\mathrm{ZrOCl}_{2}$ solution and characterized by a plot-like morphology of primary particles, which are randomly folded into larger agglomerates and aggregates resulting from rapid coagulation. $\mathrm{ZrO}_{2} \cdot n \mathrm{H}_{2} \mathrm{O}$ crystallizes upon further heat treatment with the formation of predominantly $t-\mathrm{ZrO}_{2}$ due to the inheritance of the structure of primary nanometer particles in $\mathrm{ZrO}_{2} \cdot n \mathrm{H}_{2} \mathrm{O}$, and the morphology of $t-\mathrm{ZrO}_{2}$ crystallites is close to spherical. The porous structure is represented by micropores in $a-\mathrm{ZrO}_{2} \cdot n \mathrm{H}_{2} \mathrm{O}$ and mesopores in $t-\mathrm{ZrO}_{2}$.

Long-term hydrolysis of the $\mathrm{ZrOCl}_{2}$ solution at $100{ }^{\circ} \mathrm{C}$ led to the formation of $m-\mathrm{ZrO}_{2} \cdot n \mathrm{H}_{2} \mathrm{O}$. A mixture of crystalline $m-\mathrm{ZrO}_{2} \cdot n \mathrm{H}_{2} \mathrm{O}$ and $a-\mathrm{ZrO}_{2} \cdot n \mathrm{H}_{2} \mathrm{O}$ with a predominance of the latter was formed after $36 \mathrm{~h}$ of hydrolysis and subsequent neutralization of the resulting sol with an ammonia solution. Monoclinic and tetragonal zirconia, respectively, were formed due to dehydration and crystallization during subsequent thermal treatment, and their ratio depends on the ratio of $m-\mathrm{ZrO}_{2} \cdot n \mathrm{H}_{2} \mathrm{O}$ and $a-\mathrm{ZrO}_{2} \cdot n \mathrm{H}_{2} \mathrm{O}$ in the initial precipitates. The observed excess of the content of $m-\mathrm{ZrO}_{2}$ after heat treatment relative to its content in untreated mixtures of $m-\mathrm{ZrO}_{2} \cdot n \mathrm{H}_{2} \mathrm{O}$ and $a-\mathrm{ZrO}_{2} \cdot n \mathrm{H}_{2} \mathrm{O}$ maybe since $m-\mathrm{ZrO}_{2}$ from $m-\mathrm{ZrO}_{2} \cdot n \mathrm{H}_{2} \mathrm{O}$ is a nucleus for the growth of new crystallites of $m-\mathrm{ZrO}_{2}$ from $a-\mathrm{ZrO}_{2} \cdot n \mathrm{H}_{2} \mathrm{O}$ or accelerating the transition $t-\mathrm{ZrO}_{2}$ to $m-\mathrm{ZrO}_{2}$ [28].

The increased hydration of the $\mathrm{ZrO}_{2}-\mathrm{H}(36)$ sample detected by the TG-DTA method was associated with the fact that in the first $36 \mathrm{~h}$ of hydrolysis, the polymerization of $\left[\mathrm{Zr}_{4}(\mathrm{OH})_{8}\left(\mathrm{H}_{2} \mathrm{O}\right)_{16}\right]^{8+}$ proceeded with the formation of a larger size polymer cluster and increased content of $(\mathrm{OH})$ and $\left(\mathrm{H}_{2} \mathrm{O}\right)$ due to olation and oxolation. A similar explanation for the induction period was suggested by $\mathrm{Hu}$ et al. [24] based on the results of a study of thermohydrolytic polymerization of a $\mathrm{ZrOCl}_{2}$ solution by the SAXS method. An increase in the duration of hydrolysis led to the consumption of $\left[\mathrm{Zr}_{4}(\mathrm{OH})_{8}\left(\mathrm{H}_{2} \mathrm{O}\right)_{16}\right]^{8+}$ and its oligomers for the growth of $m-\mathrm{ZrO}_{2}$ crystallites, and a regular decrease in the hydration of the resulting product. The main growth of $m-\mathrm{ZrO}_{2}$ crystallites occurred in the period from 36 to $61 \mathrm{~h}$ (Table 2), and the maximum CSR value was $3.4 \mathrm{~nm}$. This stage is limiting. The addition of a base in the synthesis by direct precipitation seems to greatly accelerate the passage of the above steps. As a result, the olation and oxolation with the formation of oligomers are less deep, which determines the X-ray amorphous nature of the precipitation product.

The growth of agglomerates $100-300 \mathrm{~nm}$ proceeds in parallel with the process of crystallite growth. The size of the agglomerates did not change after $61 \mathrm{~h}$ of hydrolysis. Agglomerates were composed of plot-like and/or rod-shaped nanocrystallites of $m-\mathrm{ZrO}_{2}$ and have a microporous structure. These resultsfor the morphology of aggregates confirm the prior results of TEM by other authors [7,24]. The plot-like and/or rod-shaped morphology of $m-\mathrm{ZrO}_{2}$ particles indicated an oriented attachment of crystallites [29].

The final scheme of the sequence of the formation of $\mathrm{ZrO}_{2} \cdot n \mathrm{H}_{2} \mathrm{O}$ during hydrolysis and precipitation based on the data of this work is shown in Fig. 6. 


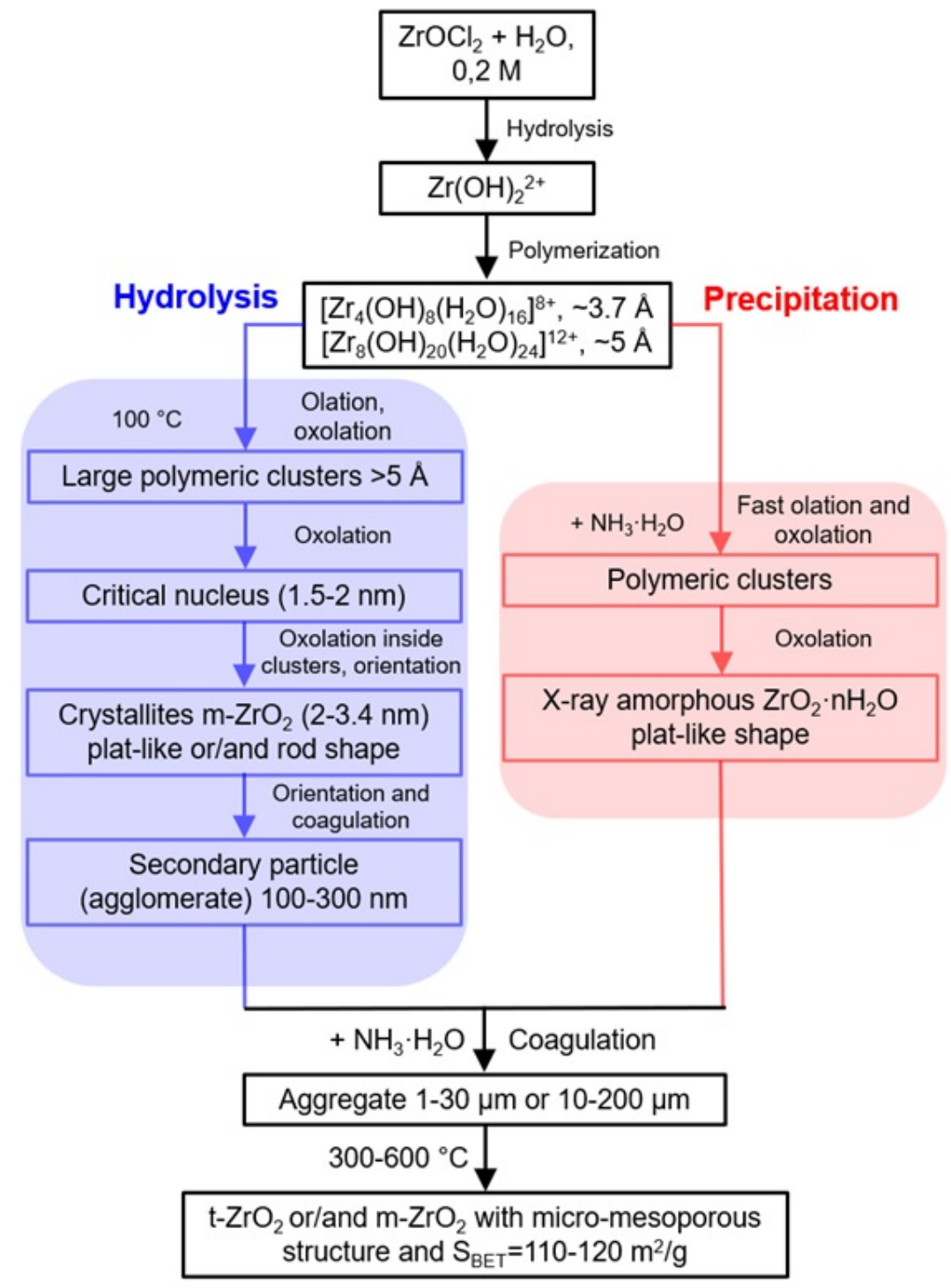

FIG. 6. Formation mechanism of $\mathrm{ZrO}_{2} \cdot n \mathrm{H}_{2} \mathrm{O}$ during hydrolysis and precipitation

The presence of polymeric zirconium hydroxocomplexes in the initial solution does not allow one to consider the formation of $\mathrm{ZrO}_{2} \cdot n \mathrm{H}_{2} \mathrm{O}$ within the framework of the classical theory of crystal growth. Comparison of the stages in Fig. 6 with nonclassical mechanisms of nucleation and growth of crystals shows that the formation of $m$ $\mathrm{ZrO}_{2}$ during hydrolysis is the closest to the mechanism of aggregation nucleation [28]. Comparison of XRD data and adsorption-structural analysis indicated that the size of the $m-\mathrm{ZrO}_{2}$ nucleus is in the range of $1.5-2 \mathrm{~nm}$, which is 4 - 6 times greater than the gyration radius of the dominant $\left[\mathrm{Zr}_{4}(\mathrm{OH})_{8}\left(\mathrm{H}_{2} \mathrm{O}\right)_{16}\right]^{8+}\left(R_{g}=3.7 \AA\right.$ [24, 27]). Rapid crystallite growth begins Wwhen the size of the $m-\mathrm{ZrO}_{2}$ crystallite reaches $2.1 \mathrm{~nm}$ after $36 \mathrm{~h}$ of hydrolysis, and this value is the upper limit. The lower value depends on the size of the oligomers formed from $\left[\mathrm{Zr}_{4}(\mathrm{OH})_{8}\left(\mathrm{H}_{2} \mathrm{O}\right)_{16}\right]^{8+}$ and its exact experimental determination by the used methods is impossible. The same range of possible critical nucleus size includes the equivalent particle size in $a-\mathrm{ZrO}_{2} \cdot n \mathrm{H}_{2} \mathrm{O}$ equal to $1.8 \mathrm{~nm}$.

\section{Conclusion}

As a result of the work, the phase formation, texture, and morphology of $\mathrm{ZrO}_{2} \cdot n \mathrm{H}_{2} \mathrm{O}$ and $\mathrm{ZrO}_{2}$ were studied depending on the hydrolysis duration of the $\mathrm{ZrOCl}_{2}$ solution followed by neutralization of the sol. It was found that the above characteristics strongly depend on the completeness of the hydrolysis of $\mathrm{ZrOCl}_{2}$ with the formation of poorly crystallized $m-\mathrm{ZrO}_{2}$. The properties of $\mathrm{ZrO}_{2} \cdot n \mathrm{H}_{2} \mathrm{O}$ and the corresponding $\mathrm{ZrO}_{2}$ obtained by hydrolysis are very different from the properties of $\mathrm{ZrO}_{2} \cdot n \mathrm{H}_{2} \mathrm{O}$ and the corresponding $\mathrm{ZrO}_{2}$ obtained by direct precipitation, which is 
due to the differences in the number of stages by which the formation of $\mathrm{ZrO}_{2} \cdot n \mathrm{H}_{2} \mathrm{O}$ occurs. The size of the critical nucleus was estimated. An important practical result was show the possibility of adjusting the ratio of $t$ - and $m-\mathrm{ZrO}_{2}$ with a constant high specific surface area exceeding the additive effect of individual $t$ - and $m-\mathrm{ZrO}_{2}$. The possibility of creating a hierarchical porous micro-mesoporous structure was also shown, which is important for the preparation of catalytic materials based on $\mathrm{ZrO}_{2}$.

\section{References}

[1] Omarov Sh.O., Pakhomov N.A. Varying the conditions of $\mathrm{ZrO}_{2} \cdot n \mathrm{H}_{2} \mathrm{O}$ precipitation and aging as a way of controlling the phase composition and texture of $\mathrm{ZrO}_{2}$. Catal. Ind., 2021, 13(1), P. 12-20.

[2] Otroshchenko T., Radnik J., Schneider M., Rodemerck U., Linke D., Kondratenko E.V. Bulk binary $\mathrm{ZrO}_{2}$-based oxides as highly active alternative-type catalysts for non-oxidative isobutane dehydrogenation. Chem. Commun., 2016, 52, P. 8164-8167.

[3] Omarov Sh.O., Vlasov E.A., et al. Physico-chemical properties of $\mathrm{MoO}_{3} / \mathrm{ZrO}_{2}$ catalysts prepared by dry mixing for isobutane alkylation and butene transformations. Appl. Catal. B., 2018, 230, P. 246-259.

[4] Omarov Sh.O., Sladkovskiy D.A., Martinson K.D., Peurla M., Aho A., Murzin D.Yu., Popkov V.I. Influence of the initial state of ZrO 2 on genesis, activity and stability of $\mathrm{Ni} / \mathrm{ZrO}_{2}$ catalysts for steam reforming of glycerol. Appl. Catal. A, 2021, 616, P. 118098 .

[5] Li J., Chen J., Song W., Liu J., Shen W. Influence of zirconia crystal phase on the catalytic performance of Au/ZrO ${ }_{2}$ catalysts for lowtemperature water-gas shift reaction. Appl. Catal. A, 2008, 334, P. 321-329.

[6] Matsui K., Ohga M. Formation mechanism of hydrous zirconia particles produced by the hydrolysis of $\mathrm{ZrOCl}_{2}$ solutions. J. Am. Ceram. Soc., 1997, 80(8), P. 1949-1956.

[7] Matsui K., Ohga M. formation mechanism of hydrous zirconia particles produced by the hydrolysis of $\mathrm{ZrOCl}_{2}$ solutions: II. J. Am. Ceram. Soc., 2000, 83(6), P. 1389-1392.

[8] Matsui K., Ohga M. Formation mechanism of hydrous zirconia particles produced by the hydrolysis of $\mathrm{ZrOCl}_{2}$ solutions: III, kinetics study for the nucleation and crystal-growth processes of primary particles. J. Am. Ceram. Soc., 2001, 84(10), P. $2302-2012$.

[9] Matsui K., Ohga M. Formation mechanism of hydrous zirconia particles produced by the hydrolysis of $\mathrm{ZrOCl}_{2}$ solutions: $\mathrm{IV}_{\mathrm{V}}$, effect of $\mathrm{ZrOCl}_{2}$ concentration and reaction temperature. J. Am. Ceram. Soc., 2002, 85(3), P. 545-553.

[10] Sharikov F.Yu., Almjasheva O.V., Gusarov V.V. Thermal analysis of formation of $\mathrm{ZrO}_{2}$ nanoparticles under hydrothermal conditions. Russ. J. Inorg. Chem., 2006, 51(10), P. 1538-1542.

[11] Raghavendra V.B., Naik S., Antony M., Ramalingam G., Rajamathi M., Raghavan S. Amorphous, monoclinic, and tetragonal porous zirconia through a controlled self-sustained combustion route. J. Am. Ceram. Soc., 2011, 94(6), P. 1747-1755.

[12] Štefanić G., Musić S., Popović S., Furić K. Formation of $\mathrm{ZrO}_{2}$ by the thermal decomposition of zirconium salts. Croat. Chem. Acta., 1996, 69, P. 223-239.

[13] Zhukov A.V., Chizhevskaya S.V., Phyo P., Panov V.A. Heterophase synthesis of zirconium hydroxide from zirconium oxychloride. Inorg. Mater., 2019, 55(10), P. 994-1000.

[14] Thommes M., Kaneko K., et al. Physisorption of gases, with special reference to the evaluation of surface area and pore size distribution (IUPAC Technical Report). Pure Appl. Chem., 2015, 87(9-10), P. 1051-1069.

[15] Toraya H., Yoshimura M., Somiya S. Calibration curve for quantitative analysis of the monoclinic tetragonal $\mathrm{ZrO}_{2}$ system by $\mathrm{X}$-ray diffraction. J. Am. Chem. Soc., 1984, 67(6), P. C119-C121.

[16] Sato T. The thermal decomposition of zirconium oxyhydroxide. J. Therm. Anal. Calorim., 2002, 69, P. $255-265$.

[17] Livage J., Doi K., Mazires C. Nature and thermal evolution of amorphous hydrated zirconium oxide. J. Am. Ceram. Soc., 1968, 51(6), P. 349353

[18] Garvie R.C. The occurrence of metastable tetragonal zirconia as a crystallite size effect. J. Phys. Chem., 1965, 69(4), P. 1238-1243.

[19] Almjasheva O.V., Lomanova N.A., Popkov V.I., Proskurina O.V., Tugova E.A., Gusarov V.V. The minimum size of oxide nanocrystals: phenomenological thermodynamic vs crystal-chemical approaches. Nanosystems: Physics, Chemistry, Mathematics, $2019,10(4)$, P. $428-437$.

[20] Mercera P.D.L., Van Ommen J.G., Doesburg E.B.M., Burggraaf A.J., Ross J.R.H. Zirconia as a support for catalysts. Evolution of the texture and structure on calcination in air. Appl. Catal., 1990, 57, P. 127-148.

[21] Srinivasan R., Rice L., Davis B.H. Critical particle size and phase transformation in zirconia: transmission electron microscopy and X-ray diffraction studies. J. Am. Ceram. Soc., 1990, 73(11), P. 3528-3530.

[22] Ceresoli D., Vanderbilt D. Structural and dielectric properties of amorphous $\mathrm{ZrO}_{2}$ and $\mathrm{HfO}_{2}$. Phys. Rev. B., 2006, 74(12), P. 125108.

[23] Hu M. Z.-C., Harris M.T., Byers C.H. Nucleation and growth for synthesis of nanometric zirconia particles by forced hydrolysis. J. Coll. Int. Sci., 1998, 198, P. 87-99.

[24] Hu M. Z.-C., Zielke J.T., Byers C.H. Small-angle x-ray scattering studies of early-stage colloid formation by thermohydrolytic polymerization of aqueous zirconyl salt solutions. J. Mater. Res., 1999, 14(1), P. 103-113.

[25] Zhao Y., Li W., Zhang M., Tao K. A comparison of surface acidic features between tetragonal and monoclinic nanostructured zirconia. Catal. Comm., 2002, 3, P. 239-245.

[26] Clearfield A., Vaughan P.A. The crystal structure of zirconyl chloride octahydrate and zirconyl bromide octahydrate. Acta Cryst., 1956, 9, P. 555-558.

[27] Walther C., Rothe J., Fuss M., Büchner S., Koltsov S., Bergmann T. Investigation of polynuclear Zr(IV) hydroxide complexes by nanoelectrospray mass-spectrometry combined with XAFS. Anal. Bioanal. Chem., 2007, 388, P. 409-431.

[28] Almjasheva O.V., Gusarov V.V. Metastable clusters and aggregative nucleation mechanism. Nanosystems: Physics, Chemistry, Mathematics, 2014, 5(3), P. 405-416.

[29] Ivanov V.K., Fedorov P.P., Baranchikov A.Y., Osiko V.V. Oriented attachment of particles: 100 years of investigations of non-classical crystal growth. Russian Chemical Reviews, 2014, 83(12), P. 1204-1222. 